\title{
Analisis Hubungan Jumlah Penduduk Dan Kepadatan Penduduk Dengan Bahan Bakar Minyak Transportasi Kota
}

\author{
Analysis of Population And Density Relationship \\ with Fuel Urban Transportation
}

Mudjiastuti Handajani ${ }^{1}$ dan Bambang Riyanto ${ }^{2}$

\begin{abstract}
Abstrak: Bahan bakar minyak (BBM) dan transportasi penting untuk dikaji karena berhubungan dengan lingkungan dan ekonomi lokal, nasional dan global. BBM untuk transportasi kota dipengaruhi oleh jumlah dan kepadatan penduduk. Tujuan penelitian adalah menganalisis kepadatan penduduk kota dan konsumsi BBM/kapita untuk kota metropolitan di dunia, di Indonesia, metropolitan Semarang dan kota besar Surakarta. Analisis yang dilakukan dengan menggunakan bivarate. Kota metropolitan negara maju menunjukkan: kota yang penduduknya semakin padat, konsumsi BBM/kapita semakin rendah. Untuk kota di Indonesia dan kota metropolitan Semarang dan kota besar Surakarta menunjukkan: kota yang penduduknya semakin padat, konsumsi BBMnya tidak selalu turun. Agar konsumsi BBM kota efisien, sistem transportasi kota menggunakan kendaraan umum massal dan dilakukan pengaturan land use yang kompak. Konsumsi BBM efisien dapat meningkatkan kesehatan dan perekonomian Negara.
\end{abstract}

Kata Kunci : BBM, hubungan, kota, kepadatan, transportasi

\begin{abstract}
Fuel oil and transport is important to study because it relates to the environment and the local economy, nationally and globally. Fuel for urban transport is influenced by the number and density of population. The purpose of the study is to analyze the population density of the city and fuel consumption/capita for metropolitan cities in the world, in Indonesia, the metropolitan city of Semarang and large city of Surakarta. The analysis is performed using bivarate. Metropolis developed countries shows: the more densely populated cities, fuel consumption/capita is the lower. For Indonesian cities and metropolitan cities of Semarang and Surakarta big show: the more densely populated city, fuel consumption does not always decreased. To be efficient fuel consumption city, the city's transportation system using mass public transportation and land use arrangements made compact. Efficient fuel consumption, can improve the health and economy of the State.
\end{abstract}

Keywords : fuel, relationships, cities, density, transportation

\footnotetext{
${ }^{1}$ Fakultas Teknik Jurusan Sipil, Universitas Semarang, Semarang, Indonesia Jalan Soekarno-Hatta Semarang 50196

2 Jurusan Teknik Sipil, Fakultas Teknik, Universitas Diponegoro

Jl. Prof Soedharto, SH - Tembalang, Semarang
} 


\section{Pendahuluan}

Peningkatan transportasi terjadi di kota besar menyebabkan peningkatan konsumsi BBM. Menurut Williams (2005), salah satu bagian transportasi berkelanjutan adalah dengan mengefisienkan konsumsi BBM secara bersama dan terpadu di seluruh dunia, dengan memperhatikan kebutuhan pada masa datang. Menurut Kenworthy dan Laube (2002), tentang kepadatan penduduk dan konsumsi BBM/kapita adalah: kepadatan penduduk kota semakin tinggi, semakin rendah konsumsi BBM/kapita. Menurut Varameth et al., (2007), tata guna lahan berhubungan dengan konsumsi BBM.

Bertraud dan Richardson (2004) menyatakan, di Asia pengaruh kenaikan kepadatan penduduk tidak menentukan konsumsi BBM/kapita, yang menentukan konsumsi BBM/kapita adalah pola perjalanan penduduk. Mudjiastuti (2011) juga meneliti kota di Indonesia yang hasilnya adalah menurunnya konsumsi BBM/kapita tidak selalu disebabkan oleh bertambahnya jumlah dan kepadatan penduduk. Pada saat ini masyarakat memperhatikan konsumsi BBM, karena BBM berasal dari fosil langka dan tak terbarukan, sehingga penggunaan BBM perlu efisiensi. Menurut Vincent and Pierre (1994), jumlah dan kepadatan penduduk dapat menentukan jenis sistem transportasi yang efisiensi BBM.

Penelitian kepadatan kota dan konsumsi BBM di negara maju sudah dilakukan, maka perlu dilakukan analisis lebih mendalam tentang hubungan kepadatan penduduk dengan konsumsi BBM untuk transportasi kota metropolitan di dunia, di Asia, di Indonesia, kota Metropolitan Semarang dan Kota Besar Surakarta. Diharapkan penelitian ini dapat digunakan oleh pengambil kebijakan bidang perencana dan transportasi kota, berkaitan dengan penyempurnaan sistem transportasi. Penelitian dengan variabel kepadatan penduduk dan konsumsi BBM belum banyak diteliti di negara berkembang, padahal ini merupakan kunci dari sistem transportasi berkelanjutan (Advait dan Kevin, 2009).

Kota adalah kumpulan lingkungan yang sangat komplek, yang sudah mengalami interelasi antar penduduk terhadap lingkungan. Hasil interelasi akan menghasilkan pola land use sesuai teori struktur kota (Rodrigue, 2004). Menurut Varameth et al. (2007), interaksi transportasi dengan land use terjadi dalam pembangunan kota, khususnya kota metropolitan. Susanto et al. (2005), menyatakan infrastruktur transportasi kota di negara maju lebih baik dari pada di negara berkembang. Menurut Rodrigue (2004), model kota dapat terbentuk dari pertumbuhan penduduk dan kepadatan penduduk kota. Hal ini sesuai dengan Zang dan Guidon (2006), yang menyatakan model hubungan terjadi karena porposi pemukiman menuju bukan pemukiman. Model kota Multi-Pusat Ullman-Harris lebih mendekati model yang nyata di lapangan dibanding model lain.

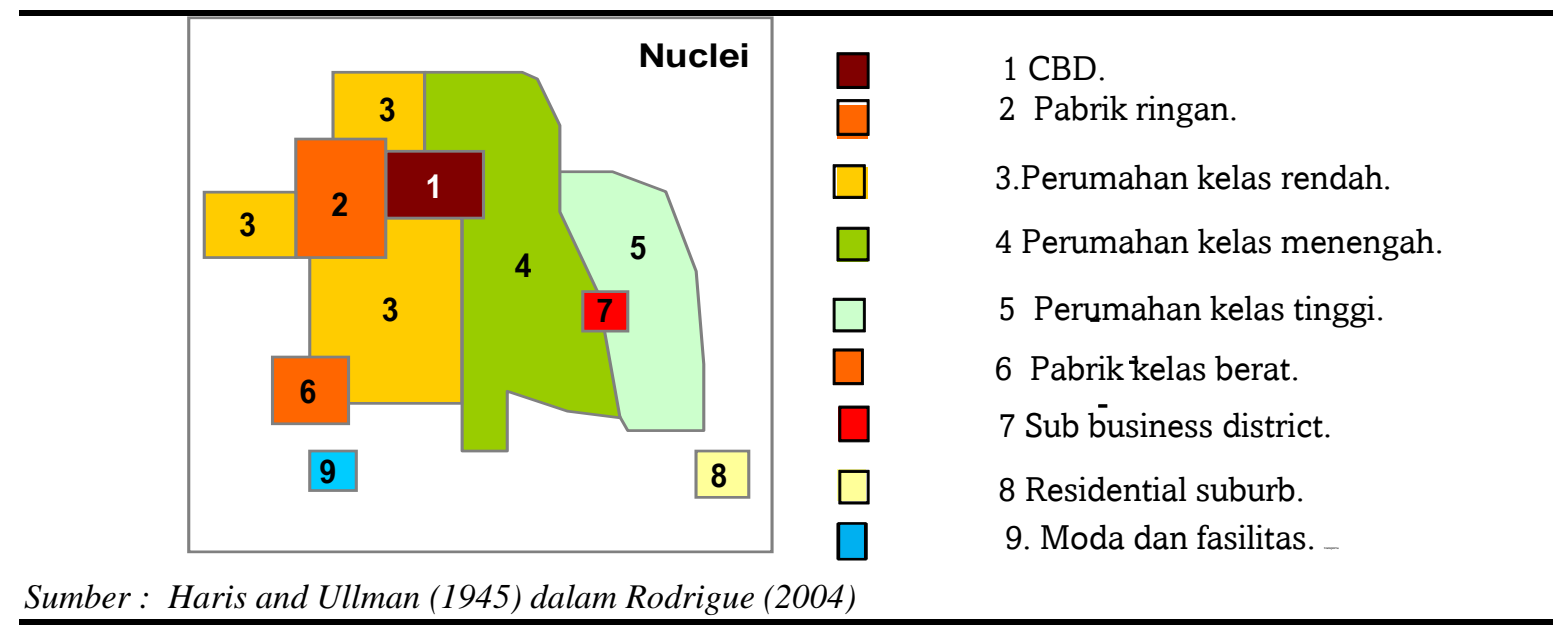

Gambar 1. Tipologi Kota Model Ullman-Harris (1945) 
Kota modern memiliki tipologi komplek, titik tumbuh terjadi di beberapa nucleus bebas, setiap inti mendorong pertumbuhan, masing-masing inti berbeda dan menyatu menjadi pusat urban besar. Jika pertumbuhan yang terjadi terlalu besar akan menimbulkan kongesti, hal ini membuat beberapa fungsi kawasan menyebar dan membentuk inti baru yang menghasilkan pertokoan pinggir kota. Hal ini karena tata guna lahan berhubungan erat dengan perkembangan kota (Gilbert, 1998). Model perkotaan Ullman-Harris tersebut dapat dilihat pada Gambar 1.

Dalam hubungannya dengan sistem transportasi kota dan konsumsi BBM, model kota di atas menunjukkan panjang perjalanan yang perbeda di setiap zona, penggunaan kendaraan dalam berpindah tempat. Sehingga konsumsi BBM penduduk di tiap zona berbeda juga. Kepadatan penduduk dan faktor lokasi, mempengaruhi penggunaan energi (Alan et al., 2007). Menurut Wegener (2003), sistem transportasi kota dan tata guna lahan memiliki korelasi yang kuat, yang dipengaruhi oleh besaran tata guna lahan dan distribusi pergerakan (gerak perjalanan, moda angkutan) serta konsumsi BBM.

Tiap tahun, jumlah penduduk mengalami pertumbuhan demikian juga peningkatan konsumsi BBM. Berdasarkan sensus penduduk Indonesia pada tahun 1971 mempunyai penduduk sebesar 119,2 juta jiwa, tahun 1980 sebesar 147,5 juta jiwa, tahun 2000 sebesar 205,1 juta jiwa, laju pertumbuhan penduduk 1,49\%. Sensus penduduk 2010 menunjukkan jumlah penduduk sebanyak 237,5 juta jiwa, seperti tertera pada Gambar 1.

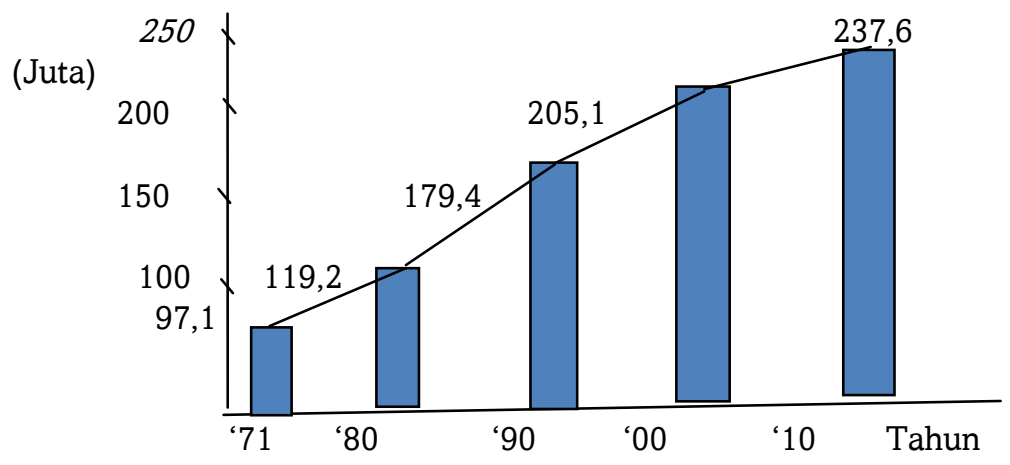

Sumber: BPS, 2011

Gambar 1. Trend Pertumbuhan Penduduk di Indonesia

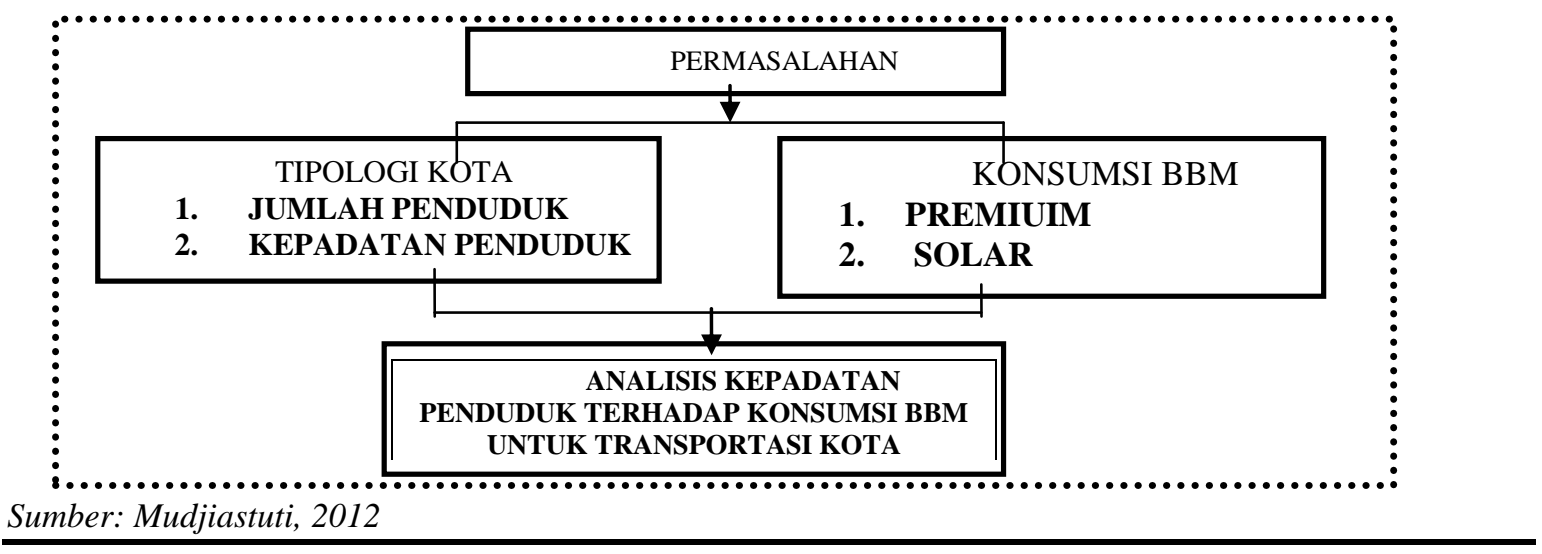

Gambar 2. Kerangka Analisa 
Konsumsi BBM dalam penelitian ini adalah besarnya BBM yang digunakan untuk transportasi jalan raya sesuai pembelian SPBU kepada Pertamina. Analisis konsumsi BBM berhubungan dengan transportasi sangat strategis dan penting. Hal ini sebagai upaya dalam manajemen lalu lintas dan sistem transportasi agar BBM hemat yang bermanfaat bagi perekonomian negara dan pembangunan berkelanjutan (Mudjiastuti, 1998 dan Sukarto, 2006). Andre et al. (2007) menyatakan bahwa konsumsi BBM akan tinggi jika orang tinggal di kota yang kepadatan penduduk rendah dan pusat kegiatan jauh dari tempat tinggalnya, sedangkan orang bertempat tinggal dekat pusat kota/kegiatan konsumsi BBMnya menjadi lebih sedikit. Sebagai landasan teori penelitian ini adalah menanfaatkan hasil penelitian tentang penduduk dan kepadatan penduduk serta konsumsi BBM kota, yang pernah dilakukan di Indonesia dan di luar negeri. Adapun kerangka analisis tentang eksplorasi variabel penelitian dapat dilihat pada Gambar 2.

\section{Pembahasan}

Analisis ini melihat hubungan antara variabel terikat dengan masing-masing variabel bebas. Variabel terikat adalah konsumsi BBM (premium, solar dan total). Variabel bebas adalah jumlah penduduk dan kepadatan penduduk. Hubungan antarvariabel terikat (premium, solar dan total), memiliki korelasi positif dan sangat kuat, artinya jika kota mempunyai konsumsi BBM premium tinggi, maka konsumsi BBM solar dan BBM total cenderung tinggi pula. Sebelum menentukan variabel jumlah penduduk dan kepadatan penduduk yang akan digunakan dalam analisis, dilakukan uji korelasi terhadap variabel yang diduga mempunyai korelasi kuat, agar tidak terjadi kolinieritas. Korelasi antara variabel jumlah penduduk kota dengan variabel konsumsi BBM menunjukkan hubungan sangat kuat, sedangkan hubungan kepadatan penduduk terhadap konsumsi BBM sangat lemah. Korelasi dan bentuk hubungan antara jumlah penduduk, kepadatan penduduk dengan konsumsi BBM dapat dilihat pada Tabel 1 di bawah ini.

Tabel 1. Jumlah Penduduk - Kepadatan Penduduk - Konsumsi BBM

\begin{tabular}{|c|c|c|}
\hline & $\begin{array}{c}\text { Kepadatan Penduduk } \\
\text { Netto } \\
\end{array}$ & Jumlah Penduduk \\
\hline Premium & cubic $(0,540)$ & linier $(0,990)$ \\
\hline Solar & cubic $(0,301)$ & power $(0,950)$ \\
\hline Total & cubic $(0,472)$ & linier $(0,970)$ \\
\hline
\end{tabular}

Sumber : Mudjiastuti (2012)

\section{Konsumsi BBM}

Rata-rata konsumsi BBM (premium+solar) kota di Indonesia adalah 3.411 .421 kilo liter/tahun, jumlah premium 2.432.872 kilo liter per tahun, solar 978.549 kilo liter per tahun. Perbandingan konsumsi BBM premium dan solar adalah sebesar 71\%:29\%. Premium lebih banyak digunakan kendaraan bermotor di Indonesia, karena jumlah kendaraan penumpang pribadi sangat tinggi (6.384.406 unit atau 99,37\% dari total kendaraan penumpang), jumlah angkutan umum penumpang rendah (40.726 unit atau 0,63\% total kendaraan penumpang), persentase jumlah sepeda motor lebih besar dari $82 \%$ dari jumlah kendaraan pribadi. Hasil penelitian menunjukkan 5\% BBM di SPBU masih digunakan di sektor lain.

Konsumsi BBM/tahun paling banyak di tahun 2008 adalah Surabaya (650.085 kilo liter/tahun), konsumsi BBM/tahun terendah adalah Mojokerto tahun 2007 (13.568 kilo liter/tahun). Sedangkan Sukabumi mempunyai konsumsi BBM/penduduk/hari tinggi (0,6 liter). Dijelaskan oleh Dinas Perhubungan Kota Sukabumi (2011): Kota Sukabumi memiliki luas daerah terbangun 19,63 km2, jumlah SPBU 12 unit. Penduduk Kabupaten Sukabumi sebagian penduduknya bertempat tinggal di sekeliling Kota Sukabumi, membeli BBM ke SPBU 
di Kota Sukabumi. Kabupaten Sukabumi mempunyai penduduk sebanyak 2.391 .736 jiwa dengan luas administrasi 4.199,7 km2, terluas di seluruh Jawa dan Bali, dengan luas daerah terbangun 4,48 \% (18,814 Ha). Jumlah penduduk Kabupaten Sukabumi hampir sama dengan jumlah penduduk Kota Bandung (2,329.928 jiwa). Bandung mempunyai 96 unit SPBU. Jumlah SPBU di Kabupaten Sukabumi 20 unit. Jadi ada kemungkinan sebagian penduduk Kabupaten Sukabumi membeli BBM di Kota Sukabumi. Konsumsi BBM rata-rata, maksimum, minimum dan jumlah SPBU dapat dilihat pada Tabel 2.

Tabel 2. Konsumsi BBM Kota di Indonesia

\begin{tabular}{clccc}
\hline No. & \multicolumn{1}{c}{ Uraian } & Maksimal & Minimal & Rata-rata \\
\hline 1. & Jumlah SPBU & 96 & 3 & 22,32 \\
2. & Konsumsi BBM Total (kl/th) & 650.260 & 13.568 & $155.064,56$ \\
& Konsumsi Premium (kl/th) & 456.962 & 9.776 & $110.585,09$ \\
& Konsumsi Solar (kl/th) premium/jumlah & 193.123 & 3.792 & $44.479,47$ \\
3. & Konsumsi BBM & 0,12 & 0,36 \\
& penduduk/hari (l) & 0,29 & 0,07 & 0,15 \\
4. & Konsumsi BBM solar/j.pdd/hr(l) & & & \\
\hline
\end{tabular}

Sumber: Mudjiastuti (2012).

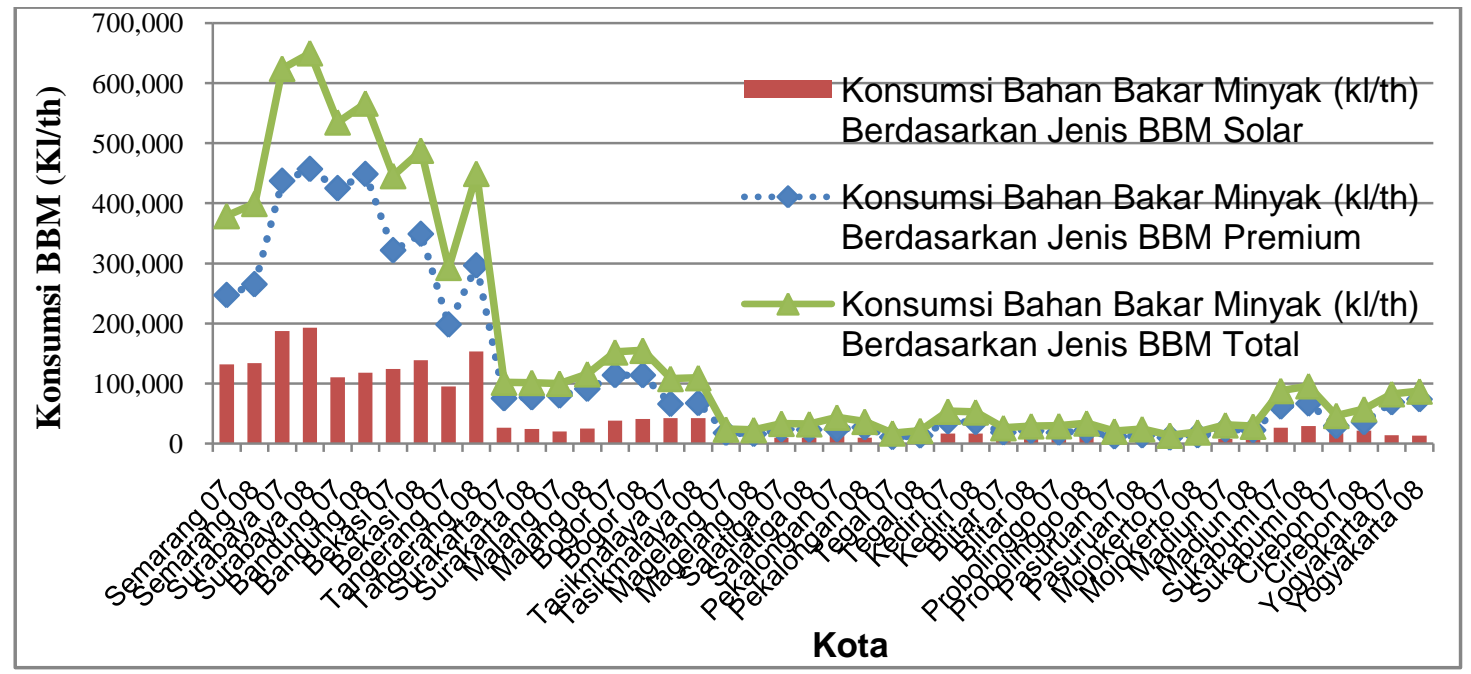

Sumber: Pertamina (2008)

\section{Gambar 3. Konsumsi BBM Tiap Kota Per Tahun (kilo liter/tahun) 2007-2008}

Pembelian BBM di SPBU tidak dibatasi oleh daerah administratif, sehingga bisa terjadi: orang membeli BBM berasal dari kota A, mengisi BBM di SPBU kota B, dan BBM digunakan di kota C. Pengendara mengisi BBM tidak selalu di kota sesuai dengan plat nomor kendaraannya dan digunakan di tempat pembelian SPBU, tetapi pengendara akan mengisi BBM di SPBU terdekat atau sejalan dengan arah asal atau tujuan (Dephubdat, 2007). Kemungkinan ini bisa terjadi di seluruh kota. BBM yang dipergunakan untuk keperluan transportasi di dalam dan di luar kota sampai sekarang belum ada data dan studinya. Di penelitian ini data BBM menggunakan data sesuai dengan pembelian SPBU kepada Pertamina dan belum dipisahkan antara penggunaan dalam kota dan luar kota.

Dari penjelasan di atas menunjukkan, data BBM berdasarkan pembelian SPBU ke Pertamina ada koreksi. Besarnya koreksi tiap kota tidak sama tergantung dari situasi dan 
kondisi tiap kota. Konsumsi BBM dihitung berdasarkan konsumsi BBM kota/tahun, Konsumsi dapat dilihat pada Gambar 3.

Luas kota ada 2 bagian, yaitu luas administrasi (bruto) dan luas daerah terbangun (netto). Luas administrasi kota berkisar antara 16,45 sampai $373,67 \mathrm{~km}^{2}$. Luas daerah terbangun berkisar antara 37 sampai 87\%. Pada tahun 2008 Kota Semarang memiliki luas administrasi paling luas yaitu sebesar $373,67 \mathrm{~km}^{2}$ dengan luas terbangun sebesar $37,48 \%$. Kota Magelang mempunyai Luas administrasi paling kecil yaitu $18,12 \mathrm{~km}^{2}$ dengan luas terbangun $86,99 \%$.

\section{Jumlah Penduduk}

Jumlah penduduk kota di Indonesia antara 115.519 - 2.896.084 jiwa. Surabaya tahun 2008 jumlah penduduknya paling banyak (2.896.084 jiwa), tahun 2007 jumlah penduduk paling sedikit Mojokerto (115.519 jiwa). Rata-rata jumlah penduduk kota 739.558 jiwa. Jumlah penduduk tiap kota dapat dilihat pada Gambar 4.

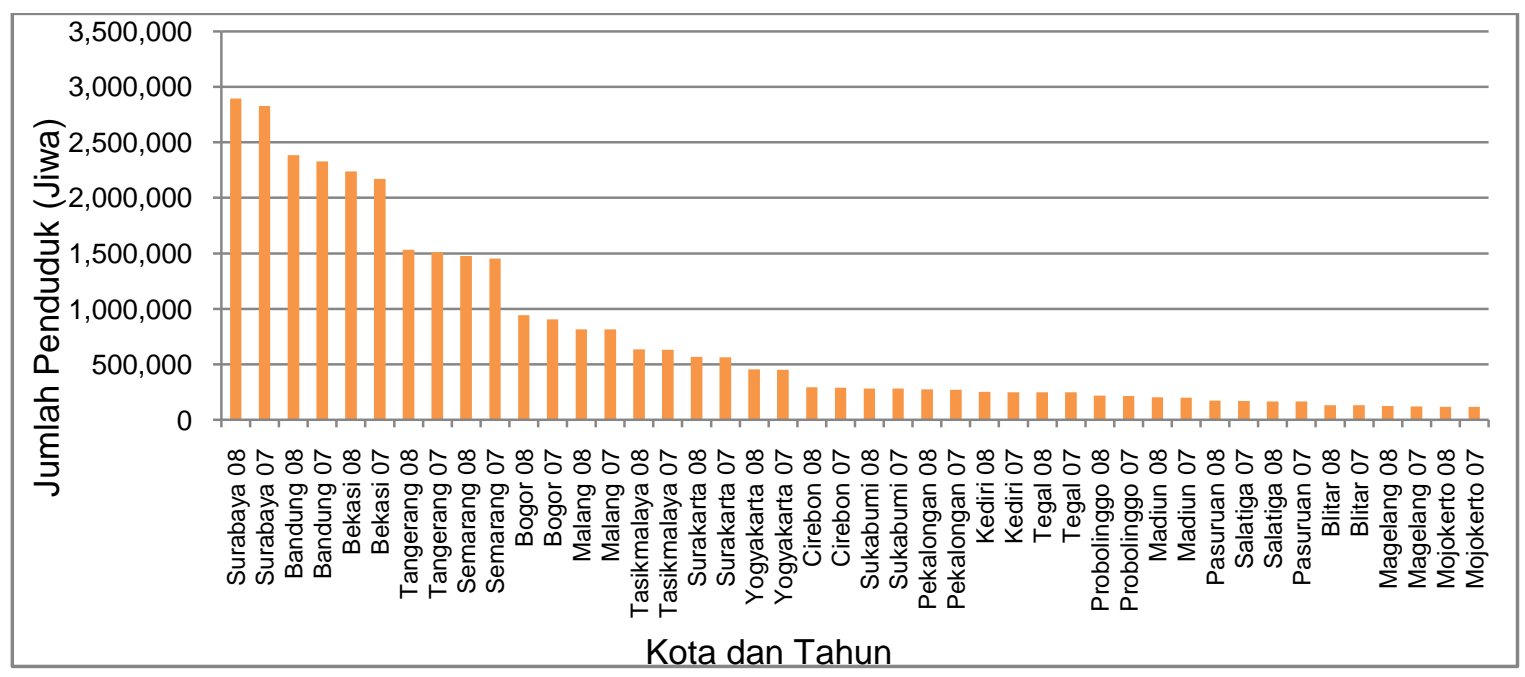

Sumber: Bambang et al.,2010

\section{Gambar 4. Jumlah Penduduk (jiwa) Tahun 2007-2008}

\section{Kepadatan Penduduk}

Kepadatan penduduk brutto adalah jumlah penduduk dibagi dengan luas administratip. Kepadatan penduduk netto adalah jumlah penduduk dibagi dengan luas daerah terbangun. Dalam hal ini kepadatan penduduk tidak dilihat penyebaran atau pengelompokkannya. Rata-rata kepadatan brutto kota-kota di Indonesia adalah sebesar $7.123,82$ orang $/ \mathrm{km}^{2}$. Rata-rata kepadatan penduduk netto adalah sebesar 12.329 orang $/ \mathrm{km}^{2}$. Kepadatan brutto dan kepadatan netto paling tinggi adalah Bandung yaitu sebesar 14.295,67 orang $/ \mathrm{km}^{2}$ dan 22.936,37 orang $/ \mathrm{km}^{2}$. Kepadatan netto paling rendah adalah Salatiga (2007) yaitu sebesar 5,503.38 orang $/ \mathrm{km}^{2}$. Kepadatan penduduk yang menyebar mempunyai panjang perjalanan lebih panjang dibandingkan dengan kepadatan penduduk mengelompok, sehingga konsumsi BBM pada kepadatan penduduk menyebar lebih tinggi dibandingkan dengan kepadatan penduduk yang mengelompok. Dari kedua kepadatan tersebut dipilih kepadatan netto sebagai variabel yang dianalisis terhadap konsumsi BBM agar tidak terjadi multikolinieritas. Kepadatan penduduk netto masing-masing kota di Indonesia dapat dilihat pada Gambar 5. 


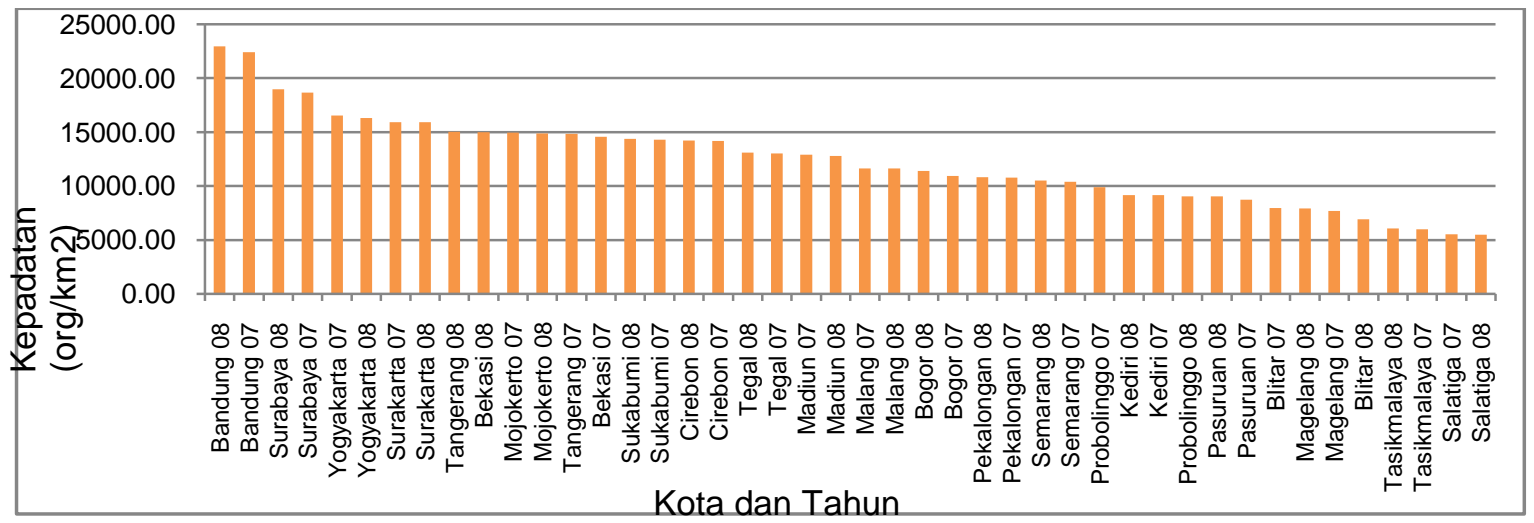

Sumber: Bambang et.al., 2010.

Gambar 5. Kepadatan Netto (org/km2) Tahun 2007-2008

\section{Hubungan Kepadatan Penduduk Netto - Konsumsi BBM}

Menurut Litman dan Stleele (2001), kepadatan penduduk cenderung mendapatkan perhatian besar untuk menurunkan konsumsi BBM, meskipun dampak perjalanan yang dihasilkan sederhana. Tetapi jika kepadatan yang biasanya berhubungan dengan faktor lain seperti aksesibilitas daerah, land use tercampur, keragaman sistem transportasi dan management parkir dilakukan secara bersama-sama akan menurunkan dampak penurunan konsumsi BBM yang besar. Oleh karena itu perlu membuat perbedaan antara difinisi sempit kepadatan sebagai atribut terisolasi dan definisi yang lebih luas (sering disebut land use yang kompak) termasuk atribut yang berhubungan dengan lainnya.

Hubungan konsumsi BBM/kapita dengan kepadatan penduduk di perkotaan, yang dilakukan oleh Newman dan Kenworthy (1999), memakai sampel sebanyak 84 kota metropolitan di dunia. Hasil yang didapat adalah kepadatan penduduk semakin tinggi, konsumsi BBM/kapita semakin rendah. Penelitian lain dilakukan oleh Bertraud dan Richardson (2004), hasilnya menunjukkan kenaikan kepadatan penduduk di Eropa Barat tidak selalu menurunkan jumlah kendaraan, yang pada akhirnya dapat menurunkan konsumsi BBM kota, disisi lain pola perjalanan penduduk di kota tersebut lebih menentukan besaran konsumsi BBM. Sedangkan menurut Doi (2007), yang meneliti kota-kota di Asia, bahwa konsumsi BBM berhubungan rendah terhadap kepadatan penduduk. Hal ini sependapat dengan Sukarto (2006), yang menyatakan pola perjalanan dipengaruhi oleh tata letak pusat kegiatan.

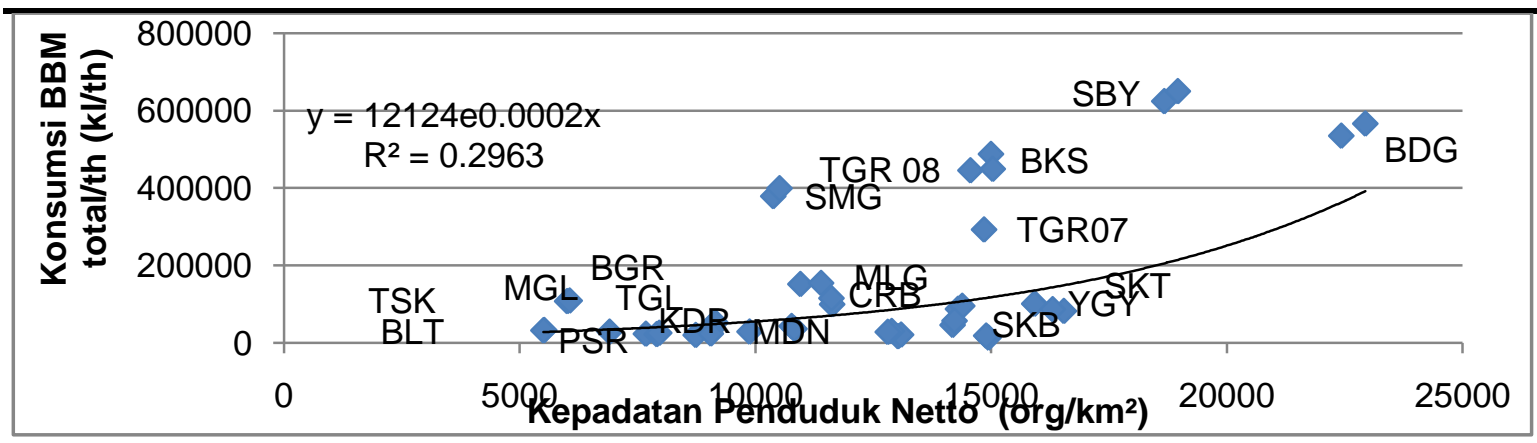

Sumber: Mudjiastuti, 2012

Gambar 6. Hubungan Kepadatan (org/km2 ) - Konsumsi BBM (kl/th) 
Penambahan kepadatan penduduk kota sedang dan besar di Indonesia lebih cepat dibandingkan dengan penambahan konsumsi BBM. Penambahan penduduk di kota sedang dan besar tidak selalu menambah kepadatan penduduk, karena daerah terbangun bergerak kearah horizontal, panjang perjalanan lebih panjang. Penambahan penduduk di kota metropolitan akan menambah kepadatan penduduk, karena daerah terbangun mendekati luas administrasinya, daerah terbangun bergerak secara vertikal, panjang perjalanan lebih pendek, meskipun kenyataan di lapangan, daerah terbangun tidak terbatas dalam luas administrasi. Hubungan Kepadatan (org/km2 ) - Konsumsi BBM (kl/th) dapat dilihat pada Gambar 6.

Jika dilihat dari hubungan kepadatan netto (orang $/ \mathrm{km}^{2}$ ) terhadap konsumsi BBM per kapita (kilo liter/tahun), untuk kota-kota di Indonesia menunjukkan penambahan kepadatan penduduk tidak selalu menurunkan konsumsi BBM/penduduk. Hubungan kepadatan penduduk netto terhadap konsumsi BBM/kapita lemah $\left(\mathrm{R}^{2}=0,149\right)$ dengan persamaan y $=$ $7 \mathrm{E}-10 \mathrm{x}^{2}-2 \mathrm{E}-05 \mathrm{x}+0,260$, seperti yang dapat dilihat pada Gambar 7 di bawah ini.

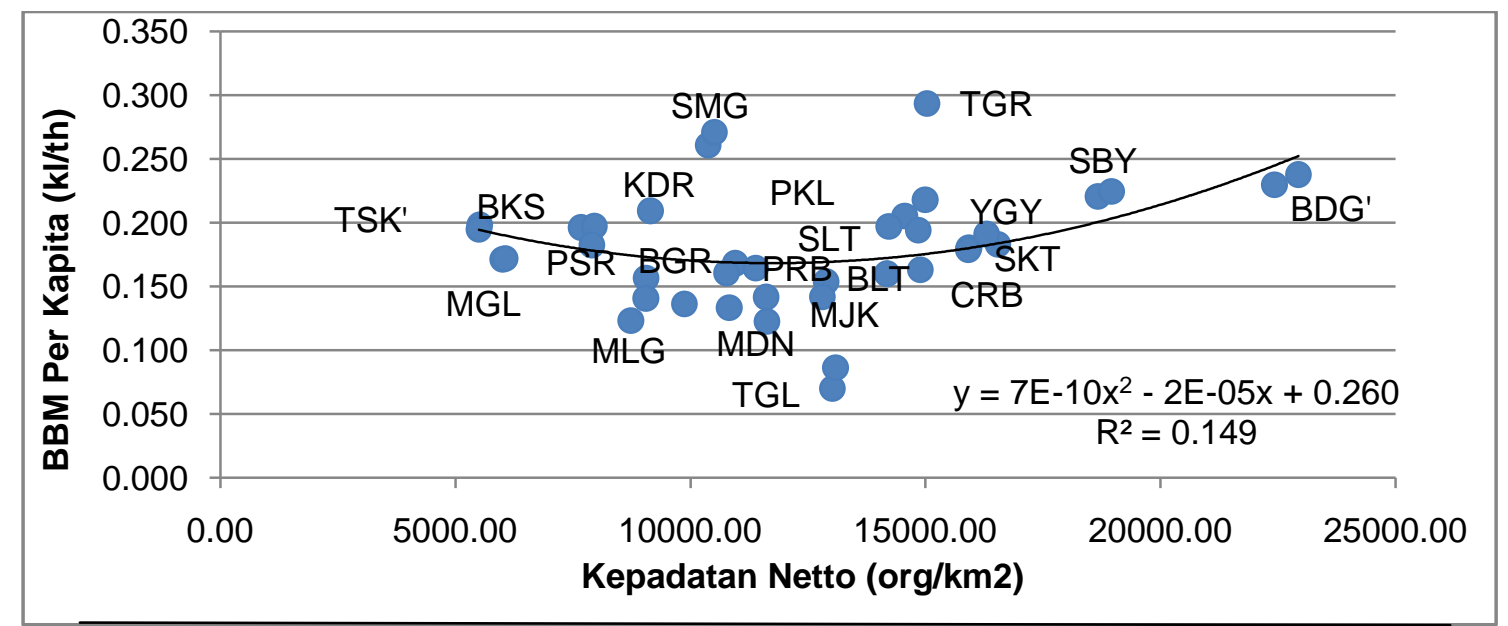

Sumber:Mudjiastuti Handajani, 2012

Gambar 7. Hubungan Kepadatan Penduduk - Konsumsi BBM Per Kapita.

Jumlah penduduk Tasikmalaya sebesar 636.458 jiwa dengan kepadatan penduduk rendah (6.060 orang $/ \mathrm{km}^{2}$ ). Konsumsi BBM/kapita sebesar 0,19 kilo liter/tahun, pola jaringan jalan radial. Tasikmalaya mempunyai kepadatan penduduk rendah, konsumsi BBM/kapita sedang, hal ini karena luasnya kota $171,56 \mathrm{~km}^{2}$ dan luas daerah terbangun sebesar 105,02 $\mathrm{km}^{2}$, sehingga panjang jalannya panjang.

Jumlah penduduk Tegal hanya 248.751 jiwa, kepadatan penduduk sebesar 13.090 orang $/ \mathrm{km}^{2}$. Konsumsi BBM/kapita rendah yaitu 0,07 kilo liter/tahun, terletak di jalur Pantura. Ada kebocoran solar sebesar $30 \%$ dari SPBU ke SPBN. Tegal mempunyai pola jaringan jalan kota bentuknya grid, jumlah Bus 2 kali lebih banyak dari jumlah MPU, penduduk dilayani angkutan umum berkapasitas besar.

Bandung mempunyai jumlah penduduk sebesar 2.383.089 jiwa dan kepadatan penduduk paling tinggi $\left(22.936\right.$ orang $/ \mathrm{km}^{2}$ ) diIndonesia, konsumsi BBM/kapita tinggi pula (0,23 kilo liter/tahun). Hal ini terjadi karena angkutan umum di Bandung masih banyak dilayani oleh MPU (kapasitas tempat duduk sedikit) jumlah kendaraan pribadi tinggi dan panjang jalan tinggi pula, pola jaringan jalan radial.

Jumlah penduduk Tanggerang sebanyak 1.531 .666 jiwa, kepadatan penduduk 15.927 orang $/ \mathrm{km}^{2}$, konsumsi BBM/kapita 0,293 kilo liter/tahun (paling tinggi). Hal ini disebabkan karena banyaknya jumlah kendaraan pribadi, sedikitnya panjang jalan, sehingga kecepatan kendaraan di ruas jalan sangat rendah. 
Surabaya mempunyai penduduk sebesar 2.896.084 jiwa dan kepadatan penduduk tinggi dan konsumsi BBM/kapita tinggi pula (0,21 kilo liter/tahun). Hal ini terjadi karena Surabaya angkutan umumnya lebih banyak menggunakan MPU dibandingkan dengan menggunakan bus, mempunyai truk dan sepeda motor tinggi.

Gambar 8 menunjukkan asumsi kepadatan penduduk, yaitu tiga distribusi kepadatan kota. Kota yang luasnya kecil tetapi penduduknya jumlahnya banyak, penambahan penduduk akan meningkatkan kepadatan dan perkembangan kota bergerak secara vertikal. Kota yang luas tetapi kecil persentase luas daerah terbangunnya, penambahan penduduk tidak menambah kepadatan karena perkembangan kota bergerak secara horisontal. Kota dengan luas yang sedang, penambahan jumlah penduduk tidak selalu menambah kepadatan penduduk (kepadatan penduduk bisa bertambah atau tetap, karena kota berkembang secara horisontal).

Kepadatan di tinjau dari jumlah kendaraan per panjang jalan, menunjukkan ada hubungan beban lalulintas dan kepadatan penduduk brutto terhadap konsumsi BBM total, dengan menghitung jumlah kendaraan/panjang jalan dan kepadatan penduduk netto/jari-jari

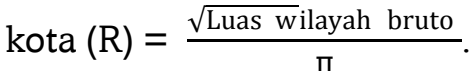

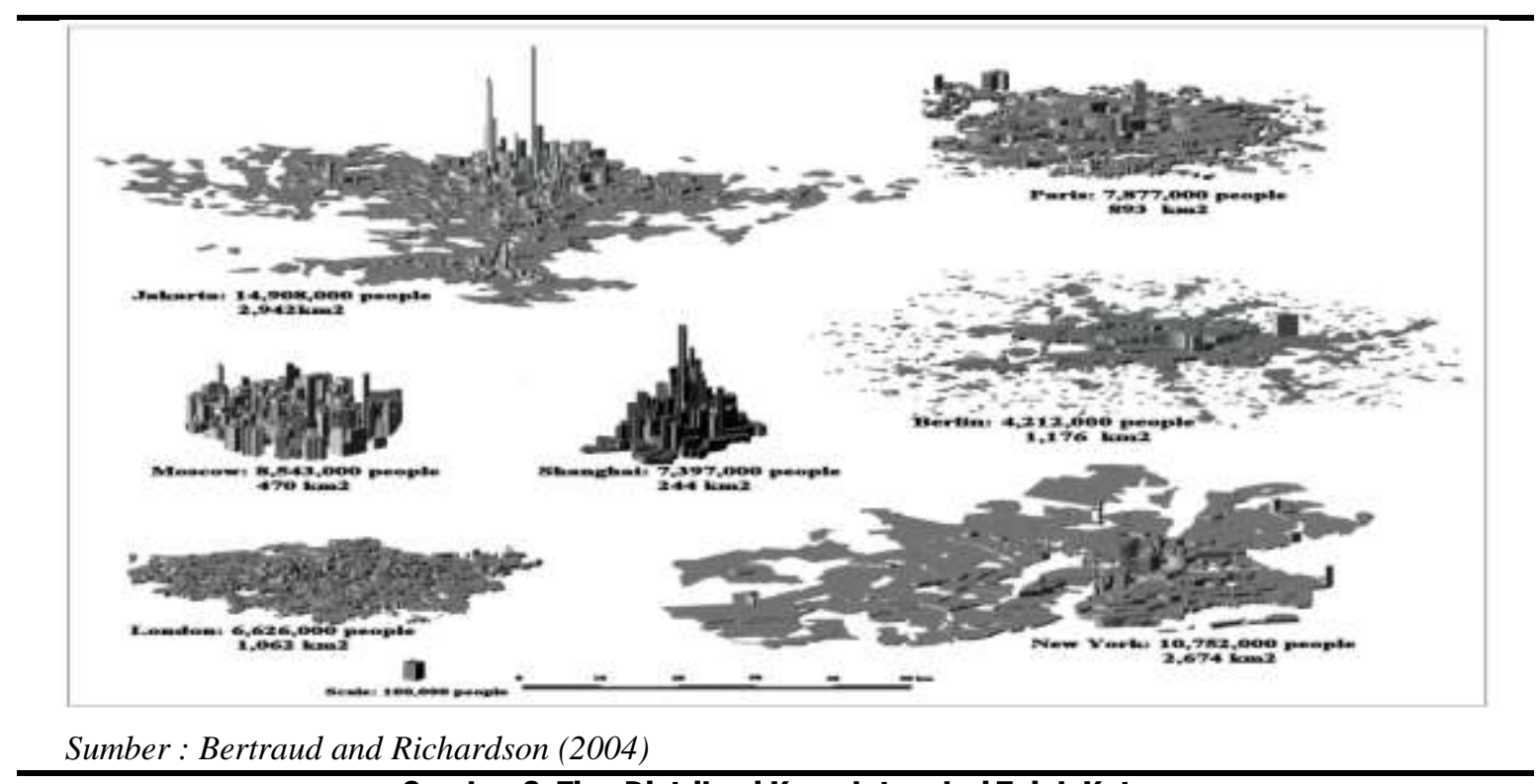

Gambar 8. Tiga Distribusi Kepadatan dari Tujuh Kota

Beban lalulintas kota ditunjukkan dari hubungan antara kepadatan penduduk brutto dengan konsumsi BBM total yang mempunyai korelasi rendah $\left(\mathrm{R}^{2}=0,134\right)$ dengan persamaan $\mathrm{y}=0,827 \mathrm{x}^{-0,2}$, karena kepadatan netto/R (jari-jari kota) sangat rendah dan konsumsi $\mathrm{BBM} /$ kapita juga rendah, dapat dikatakan, semakin besar kepadatan netto/R, maka konsumsi BBM/kapita cenderung turun (Gambar 9). Jika hubungan beban lalulintas dan kepadatan penduduk brutto terhadap konsumsi BBM menghasilkan sudut $\alpha$ yang kecil, penduduk bergerak dalam jarak lebih pendek dan alternatif lebih sedikit (Gambar 10A dan 10B), maka konsumsi BBM rendah, jika sudut $\alpha$ yang dihasilkan besar, penduduk dapat bergerak dalam jarak lebih panjang dan alternatif lebih banyak, sehingga konsumsi BBM di kota tinggi (Bertraud dan Richardson, 2004).

Semarang mempunyai penduduk sebesar 1.474.144 jiwa, luas administrasi seluas $373,67 \mathrm{~km}^{2}$ kepadatan penduduk tidak tinggi (10.512 orang/ $\mathrm{km}^{2}$ ), konsumsi BBM/kapita sebesar 0,26 kilo liter/tahun, nomer dua paling tinggi. Hubungan kepadatan netto (penduduk $/ \mathrm{km}^{2}$ ) dengan BBM tahun/kapita menunjukkan: pertambahan jumlah penduduk 
tidak selalu menambah kepadatan penduduk, karena daerah terbangun bertambah secara horisontal, sehingga panjang perjalanan tetap panjang dan konsumsi BBM akan meningkat. Penduduk Kota Semarang lebih banyak terkonsentrasi di "Kota Bawah" hal ini mengakibatkan kepadatan penduduk kota bawah menjadi tinggi. Gambar 11 menunjukkan hubungan kepadatan netto terhadap BBM total/penduduk Kota Semarang tahun 2002-2011.

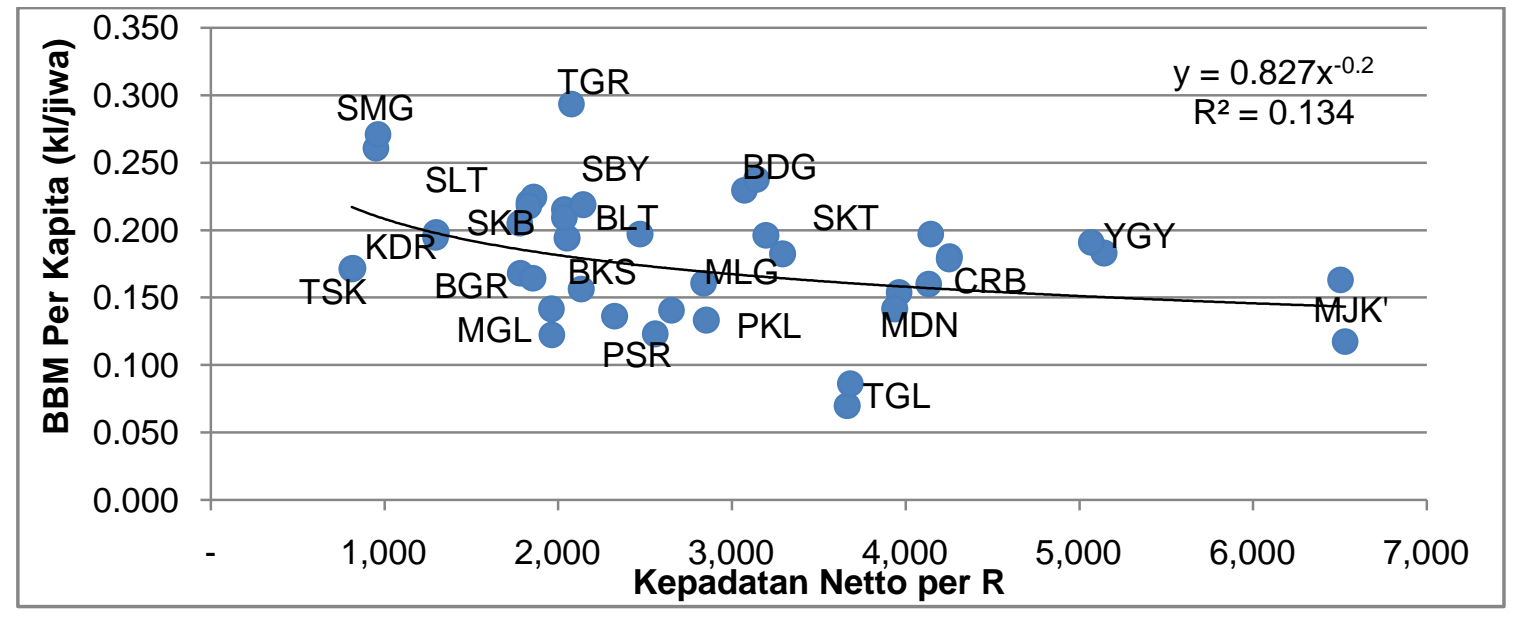

Gambar 9. Korelasi Kepadatan Netto/ $\sqrt{ }$ Luas Bruto/ $\pi$ - Konsumsi BBM/Kapita.

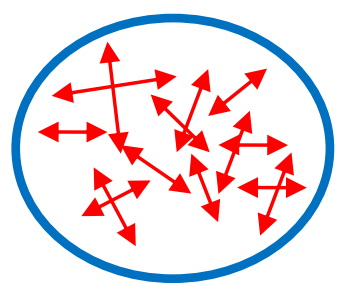

(a) Sudut a Kecil

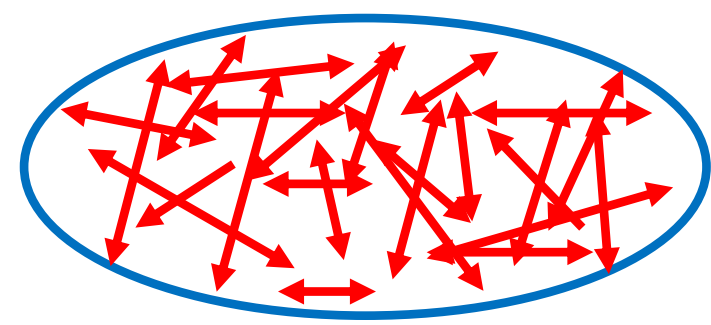

(b) Sudut a Besar Gambar 10A Kepadatan yang Sama dengan Luas yang Berbeda

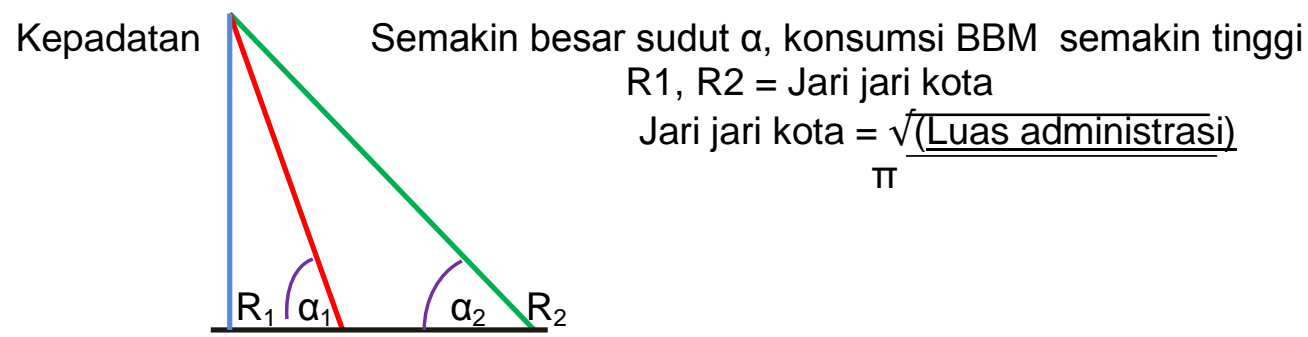

Gambar 10B. Kepadatan Bruto dan Jari-jari Kota 


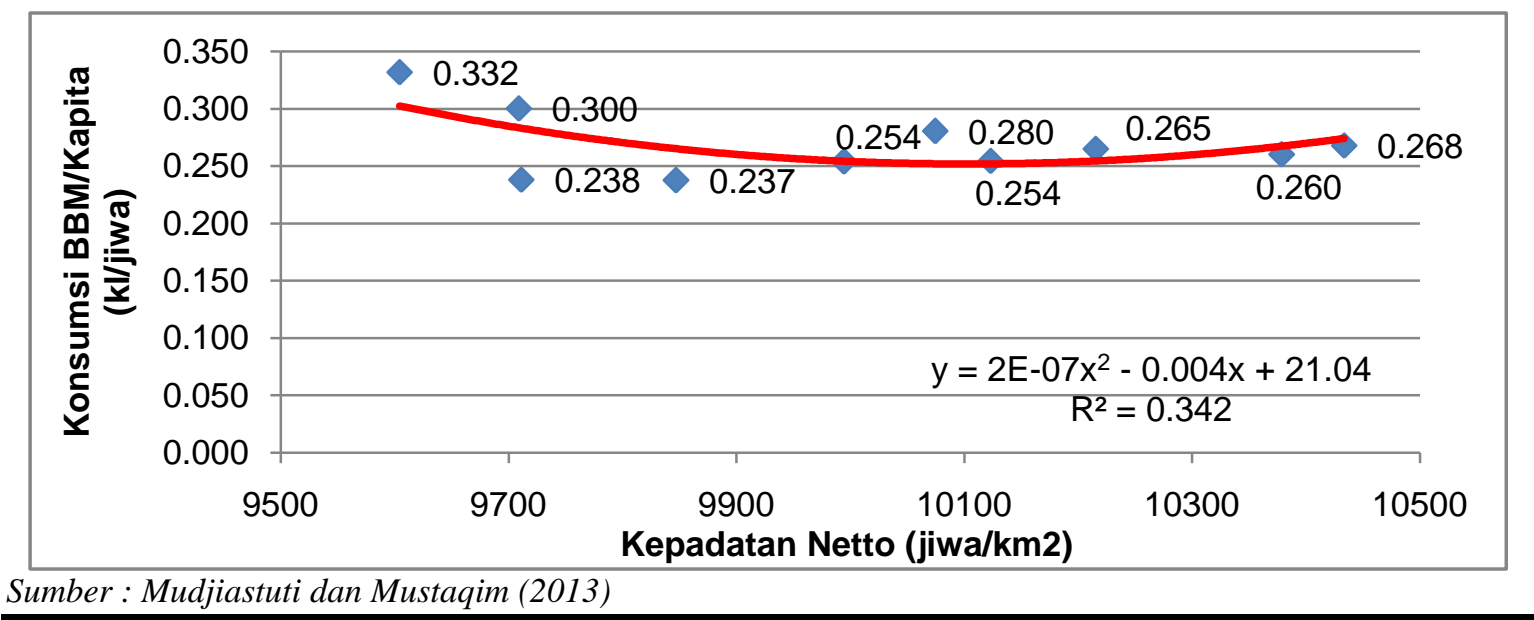

Gambar 11. Kepadatan Netto - BBM/Penduduk Kota Semarang Tahun 2002-2011

Surakarta (kota besar) mempunyai kepadatan penduduk cukup tinggi yaitu sebesar 15.915 orang $/ \mathrm{km}^{2}$ dan mempunyai konsumsi BBM/kapita tidak terlalu tinggi $(0,18$ kilo liter/tahun). Penyebaran penduduk merata sehingga tidak terjadi konsentrasi penduduk pada wilayah tertentu. Konsumsi BBM pada kepadatan penduduk merata, lebih rendah bila dibandingkan dengan kepadatan penduduk yang tidak merata. Gambar 12 menunjukkan hubungan kepadatan netto terhadap BBM total/penduduk Kota Semarang.

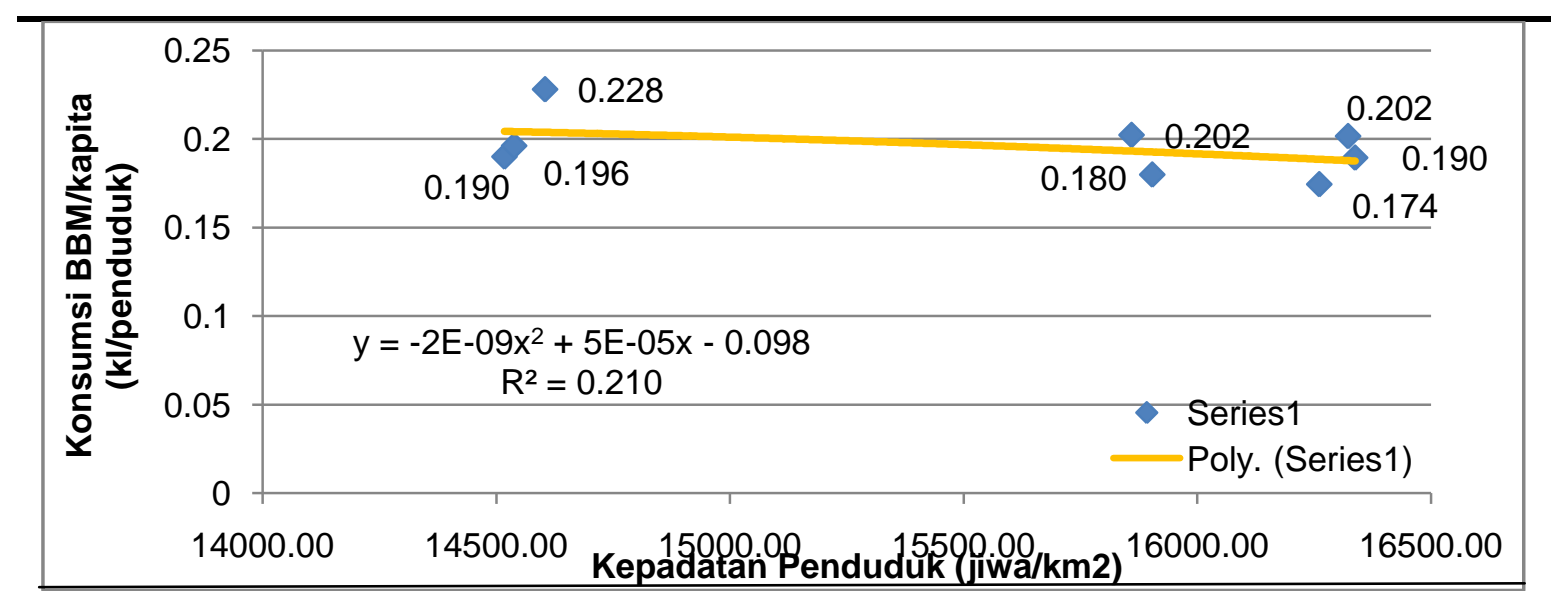

Sumber : Mudjiastuti dan Mustaqim (2013)

\section{Gambar 12. Kepadatan - BBM/Penduduk Kota Surakarta tahun 2002-2011}

Hasil analisa beberapa penelitian di atas menunjukkan bahwa kota Indonesia mempunyai kepadatan penduduk antara 5.520 orang $/ \mathrm{km}^{2}$ sampai 22.426 orang $/ \mathrm{km}^{2}$. Penggunaan lahan kota berkembang secara horizontal, penataan land use masih kurang efisien. Seharusnya permukiman bergerak secara vertikal, lahan hijau tersedia luas, kebutuhan penduduk setempat diberikan fasilitas yang memadahi, sehingga panjang perjalanan menjadi lebih pendek. Jumlah angkutan umum di masing-masing kota sangat kecil 0,63\% dari jumlah kendaraan yang ada di kota tersebut. Jumlah yang sangat kecil ini hanya dapat melayani penumpang sangat sedikit $(7 \%)$ dari jumlah penduduk yang ada. Penduduk lebih banyak menggunakan kendaraan pribadi sepeda motor atau mobil penumpang pribadi dibandingkan dengan menggunakan angkutan umum. Kenaikan kepadatan penduduk kota tidak selalu 
menurunkan konsumsi BBM/kapita. Untuk menentukan klasifikasi ruang, kota mempunyai permasalahan yang kompleks dan setiap kota adalah unik (Bertraud dan Richardson, 2004). Banyak kota mempunyai format struktur ruang kota yang tidak sama, sehingga diperlukan analisis data dalam mendiskripsikan pola ruang, yang dapat diukur dengan distribusi penduduk terhadap luas terbangun. Demikian juga menurut Breheny (2007), kepadatan kota tidak selalu menurunkan konsumsi BBM, effek kemacetan dan berpencarnya pusat kegiatan dapat menambah panjang perjalanan.

Menurut Kenworthy (2003), semakin besar kepadatan penduduk kota, konsumsi BBM/kapita semakin rendah. Kota-kota di Eropa mempunyai kepadatan penduduk 25-75 orang/ha, konsumsi BBM 10- 20 gigajoule/kapita/tahun, konsumsi BBM/kapita cukup tinggi. Kota yang diteliti, mempunyai kepadatan penduduk rendah, konsumsi BBM tinggi. Australia dan Asia (Singapura, Tokyo, Hongkong), kepadatan penduduk 75-125 orang/ha, konsumsi BBM 8-10 gigajoule/kapita/tahun. Singapura berpenduduk 4,351 juta jiwa, luas $699 \mathrm{~km}^{2}$, kepadatan penduduk 6.222 jiwa/ $\mathrm{km}^{2}$, PDRB 124.681 Juta US\$. Pada tahun 2010, 85\% penduduk dapat diangkut oleh angkutan umum MRT dan bus (APERC, 2005).

Bangkok mempunyai jumlah penduduk 5,48 juta jiwa, luas administrasi $1.568 \mathrm{~km}^{2}$ dan kepadatan penduduk 3.495 orang/ $\mathrm{km}^{2}$, PDRB 151 milyar dolar, konsumsi BBM sebesar 2.842 $\mathrm{kl} /$ tahun. Hongkong mempunyai penduduk 4,2 juta jiwa (1991), kepadatan penduduk sangat tinggi > 350 orang/ha, konsumsi BBM 5 gigajoule/kapita/ tahun. Kota dibentuk dan direncanakan dengan sangat terpadu, sehingga konsumsi BBM efisien dan berwawasan lingkungan.

Kota di Asia negara maju, seperti Tokyo, Singapura, Bangkok, mempunyai hubungan kuat antara kepadatan penduduk (orang/ $\mathrm{km}^{2}$ ) - konsumsi BBM/penduduk (kilo liter/jiwa), semakin tinggi kepadatan penduduk, semakin rendah konsumsi BBM/kapita (APERC, 2005). Kota dengan kepadatan penduduk tinggi, umumnya panjang perjalanan lebih pendek, kota memberikan fasilitas penduduk yang dapat dijangkau dengan berjalan kaki, sehingga mengurangi konsumsi BBM/kapita. Tokyo menggunakan jalan rel sejak 1920 dan merupakan kebijakan nasional yang modern. Penduduk Tokyo 73\% menggunakan commuter, 9\% kendaraan pribadi, lainnya menggunakan bus, sepeda dan berjalan kaki karena lokasi parkir yang sedikit, resiko kecelakaan dan kemacetan lalulintas (Nakamura et al., 2004). Tokyo adalah kota megapolitan di dunia yang orientasi transportasinya menggunakan transportasi umum (Cervero, 1998). Menurut Ivan dan Galindo (2005) commuting merupakan diantara penyelesaian dari kepadatan penduduk, aksessibilita, pendapatan dan ratio pekerjaan.

Gambar 12 menunjukkan hubungan antara kepadatan penduduk dan konsumsi BBM/kapita kota metropolitan di dunia dan kota-kota di Indonesia termasuk kota metropolitan Semarang dan Kota Besar Surakarta. Kota mempunyai kepadatan penduduk yang berbeda-beda, dari kepadatan penduduk rendah $\left(6.007\right.$ orang $\left./ \mathrm{km}^{2}\right)$ sampai kepadatan penduduk tinggi $\left(22.936\right.$ orang $/ \mathrm{km}^{2}$ ). Hampir semua kota, Semarang dan Surakarta jika dimasukkan ke dalam grafik Kenworthy (2003), posisinya berada di sebelah bawah, artinya konsumsi BBM/kapita di Indonesia lebih rendah dari konsumsi BBM/kapita di negara maju, hal ini sesuai dengan pendapat Mudjiastuti (2010).

Vincent dan Pierre (1994) menyatakan bahwa kepadatan penduduk tinggi, transportasi kota sebaiknya menggunakan sistem angkutan umum, sehingga penduduk dapat menggunakan transportasi untuk keperluan kehidupan, bekerja di berbagai tempat, dapat dilayani. Menurut Gerald (2004), kepadatan penduduk kota dan transportasi kota merupakan kunci utama untuk menggambarkan konsumsi BBM. Perbedaan kebijakan dalam pelaksanaan sistem transportasi kota, sarana dan prasarana yang tersedia, serta kondisi ekonomi (PDRB), membuat perbedaan konsumsi BBM. Konsumsi BBM kota di Asia lebih tergantung dari pola pergerakan penduduk dari pada kepadatan penduduk dan masing-masing sistem transportasi yang digunakan (Doi, 2007). Menurut Karathodorou et al. (2007), kepadatan kota berhubungan dengan konsumsi BBM yang variasinya lebih tergantung dari jumlah kendaraan dan panjang perjalanan, dari pada konsumsi BBM kendaraan $/ \mathrm{km}$. Menurut Litman dan Steele 
(2001), kepadatan kota meningkat akan mengurangi kepemilikan kendaraan dan panjang perjalanan serta meningkatkan penggunaan moda alternatif.

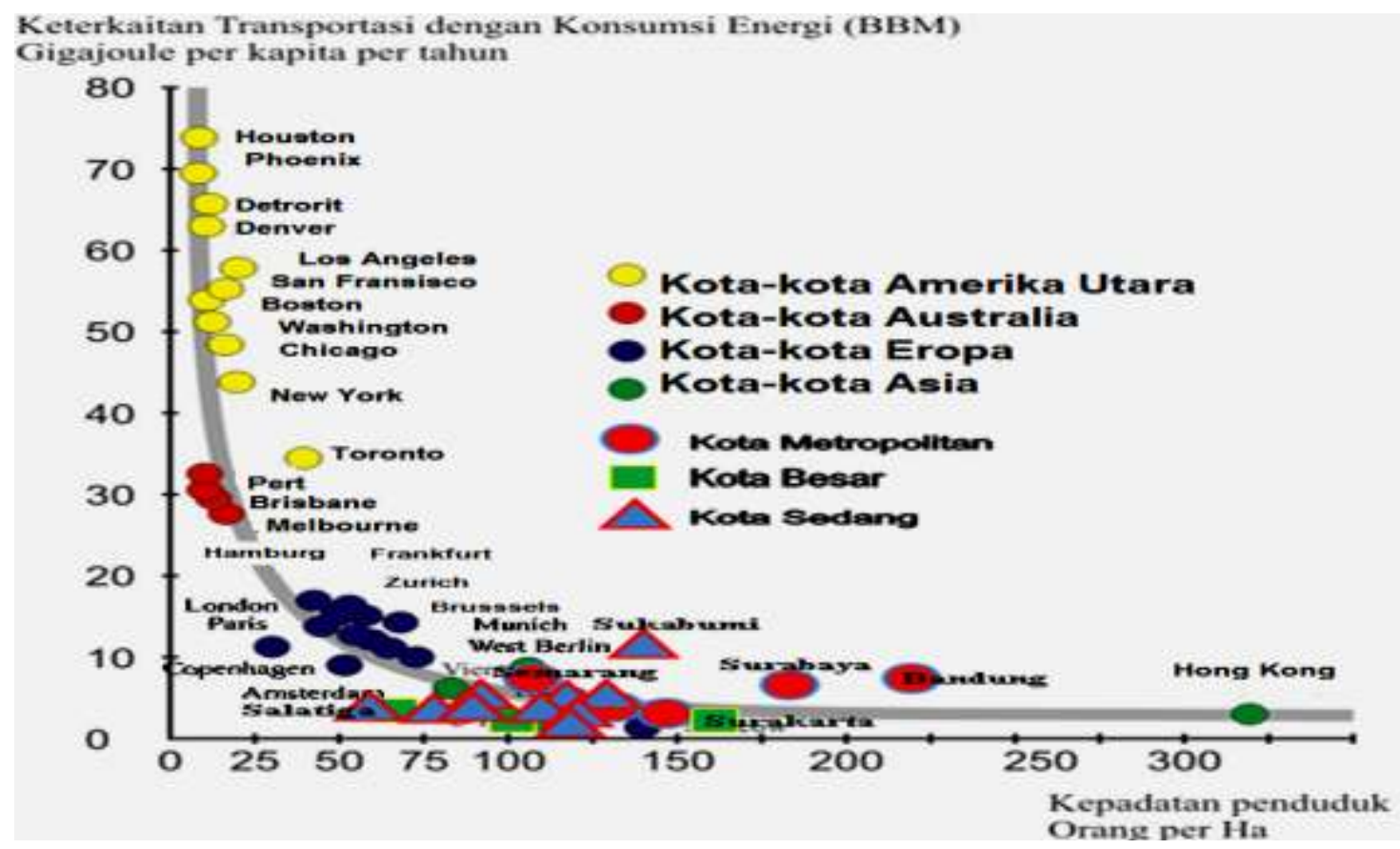

Sumber: Kenworthy (2003); Mudjiastuti (2012)

\section{Gambar 12. Grafik Hubungan antara Kepadatan Penduduk - Konsumsi BBM/kapita Kota di Dunia, di Jawa, Semarang, Surakarta}

\section{Kesimpulan}

Dengan meningkatnya kepadatan penduduk cenderung untuk mengurangi pemilikan kendaraan per kapita antara 10-20\% (Faucett dan Sierra, 1999; Ewing, Pendall dan Chen 2002; Kuzmyak dan Pratt 2003; TRB 2009). Vincent dan Pierre (1994) menyatakan bahwa kepadatan penduduk kota yang tinggi, sistem transportasi kota sebaiknya penataan land use yang kompak, menggunakan sistem angkutan umum kapasitas besar, sehingga penduduk dapat menggunakan transportasi untuk keperluan kehidupan, bekerja di berbagai tempat dapat dilayani. Kepadatan kota dan transportasi kota merupakan kunci utama untuk menggambarkan konsumsi BBM (Gerald, 2004).

\section{Daftar Pustaka}

Advait, V. and Kevin, T., 2009, The Role of VGI in Modelling Future Energy Demand, Dapartement of Eart and Atmospheric Sciences, 550 Stadium Mall Drive, Purdue University, West Lafayette, USA.

Alan, Perkins, Steve, Hamnett, Stephen Pullen, Rocco Zito dan David Tribilcock, 2007, Transport Housing and Urban Form, The life Cuclye Transport and Housig Impact of City Centre Apartements Compared with suburban dwellings, SOAC, ISBN 978-0-646-48194-4.

Andre Dantas, Susan Krumdieck, Shannon Page, 2007, Risk of Energy Constrained Activity-Transport System (RECATS), Journal of The Eastern Asia Society for Transportation Studies, Vol. 7, 1154-1168.

APERC (Asia Pacific Energy Research Centre), 2005, Urban Development and Transportations Energy Demand Motorisation in Asian Cities, Naoko DOI. 
Bambang Riyanto, Pinardi, Mudjiastuti Handajani, 2010, Analisis Hubungan Sistem Transportasi Kota Terhadap Pola Konsumsi BBM (kota metropolitan, kota besar, kota sedang di Jawa), Dirjen Dikti-Universitas Diponegoro.

Bambang Riyanto, Pinardi, Mudjiastuti Handajani, 2010, Analisis Hubungan Karakteristik Sistem Transportasi Kota-Kota di Jawa Terhadap Konsumsi BBM Dengan Menggunakan BIPLOT, Prosiding Simposium FSTPT 13, ISBN 979-95721-2-13.

Bertraud A. and Richardson, W., 2004, a. Transit and Density: Atlanta, The United States and Western Europe, in Urban Sprawl in Western Europe and The United States, Urban Planning and Environment, Ashgate.

Bertraud, A. and Richardson. W., 2004, b. the United States and Western Europe, in Urban Sprawl in western Europe and United States, Urban Planning and Environment, Ashgate.

Breheny, M., 2007, Compact City and Transport Energy Consumption, JSTOR, on line Journal.

Cervero R (1998) The transit metropolis: a global inquiry. Island Press, Washington, DC

Departement Perhubungan Darat, 2007, Perumusan Strategi dan Kebijakan Transportasi Darat untuk Penghematan Energi.

Doi Naoko, 2007, Urban Transport Energy Use in the APEC Region Trend and Option, Asia Pacific Energy Research Centre.

Reid Ewing, Rolf Pendall and Don Chen (2002), Measuring Sprawl and Its Impacts, Smart Growth America (www.smartgrowthamerica.org).

Faucett Jack and Sierra Research (1999), Granting Air Quality Credit for Land Use Measures;Policy Options, Office of Mobile Sources, USEPA (www.epa.gov).

Gerald Mills, 2004, Urban Form Function and Climate, Dept. of Geografi, UCD.

Gilbert Richard, 1998, Government Action to Guide Land-Use and Urban Development, Action for Sustainable Urban Transportation, Workshop on Land-Use Planning for Sustainable Urban Transports Implementing Change, Linz, Austria.

Ivan Muniz, Anna Galindo, 2005, Analysis Urban form and the ecological footprint of commuting the case of Barcelona, Ecological Economics 55. 499-514.

Kenworthy J., 2003, Transport Energy Use and Greenhouse Gases in Urban Passenger Transport System: A Study of 84 Global Cities, Presented to the international Third Conference of the Regional Government for Sustainable Development, Notre Dame University, Fremantle, Western Autralia.

Kenworthy J. dan Fellix Laube, 2002, Urban Transport Patterns in a Global Sample of Cities and Their Linkages to Transport Infrastructure, Land-use, Economics and Environment.

Kuzmyak Richard J. and Pratt Richard H (2003), Land Use and Site Design: Traveler Response to Transport System Changes, Chapter 15, Transit Cooperative Research Program Report 95, Transportation Research Board (www.trb.org); at http://gulliver.trb.org/publications/tcrp/tcrp_rpt_95c15.pdf.

Litman Todd and Rowan Steele, 2001, Land Use Impacts on Transport, How Land Use Factors Affect Travel Behavior, Victoria Transport Policy Institute.

Mudjiastuti Handajani, 1998, Evaluasi Ukuran Kendaraan Angkutan Umum di Semarang Ditinjau Dari Sisi TeknisEkonomi dan Lingkungan (Studi Kasus Pedurungan-Mangkang), Program Pasca Sarjana Universitas Gajah Mada, Jogjakarta.

Mudjiastuti Handajani, 2010, Analisis Struktur Kota di Jawa Terhadap Konsumsi BBM Dengan Menggunakan BIPLOT, Journal Media Komunikasi Teknik Sipil.

Mudjiastuti Handajani, 2011, Model of the Urban Transport System in Java on City Fuel Consumption, World Academi of Science, Engineering and Technology, an International Journal of Science, Engineering and Technology, WASET, Cemal Ardil, Paris, issue November 2011.

Mudjiastuti Handajani, 2011, The Influence Of The Urban Transport System In Java On City Fuel Comsumption, Proceeding of the $4^{\text {th }}$ ASEAN Civil Engineering Conference, UGM, Yogyakarta.

Mudjiastuti Handajani, 2012, Non Linear Model City Transportation System and Control of Fuel Consumptiom, International Journal of Computational Engineering Research (IJCER) Vol 2 Issue 2 pp 228-235, ISSN 22503005.

Mudjiastuti Handajani, 2012, Model Pengaruh Sistem Transportasi Kota di Jawa Terhadap Konsumsi BBM, Konferensi Nasional Teknik Sipil 2012, Program Pascasarjana, ITB, Bandung.

Mudjiastuti Handajani, 2013, The Influence Of Urban Transport System In Java On Fuel Consumption, Nigerian Journal Of Technology, Vol 32, July 2013, ISSN 1115-8443, pp 170-183

Mudjiastuti dan Mustakim, 2013, Analisis Konsumsi BBM Kota Semarang dan Kota Surakarta Ditinjau dari Sistem Transportasi Kota dan Tipologi Kota, Proceeding Symposium FSTPT XVI, Surakarta

Nakamura H, Ieda H et al (2004) Infrastructure of Tokyo (Tokyo No Infurasutorakuchaa), 2nd edn. Gihoudou. 
Newman, P.W.G dan Kenworthy J., 1999, Sustainability and Cities: Overcoming Automoble Dependence Washington $D C$. Island Press.

Pertamina, 2008, Konsumsi BBM Kota, Jakarta.

Rodrigue Jean-Paul, 2004, Transportation and The Environment, Dept. of Economics \& Geography Hofstra University, Hempstead, NY, 11549 USA.

Sukarto H, 2006, Transportasi Perkotaan dan Lingkungan, Jurnal Teknik Sipil vol.3 no 2.

TRB (2009), Driving And The Built Environment: The Effects Of Compact Development On Motorized Travel, Energy Use, And CO2 Emissions, Special Report 298, Transportation Research. Board (www.trb.org); at www.nap.edu/catalog.php

Varameth V., Kazuaki Miyamoto, Viroj Rujopakarn, 2007, An Empirical Study of Land Use/Transport Interaction in Bangkok With Operational Model Applicaion, Journal of The Eastern Asia Society for Transportation Studies, Vol. 7, 1250-1265.

Vincent F., and Piere M., 1994, High Urban Densities a Solution For Our Cities, Consulate General of France in Hongkong And French Institute of Town Planning.

Wegener Michael, 2003, A Land Use - Transportation Perspective of Urban Processes.

Williams K., 2005, Spatial Planning, Urban Form and Sustainable Transport: An Introduction.

Zang, Y. dan Guidon B., 2006, Using Satellite Remote Sensing to Survey Transport Related Urban Sustainability Part 1: Methodologies for Indikcator Quantification, International Journal of Applied Earth Observation and Geo-information, 8, 149-164. 